Тања Ж. Илић

Универзитет у Београду

Филолошки факултет

Докторске студије српског језика

tanja.ilic.90@gmail.com
Стручни рад

УДК 821.163.41.09 Pavlović М.

DOI: $10.19090 / \mathrm{mv} .2020 .11 .29-43$

\title{
ЛИНГВОСТИЛИСТИЧКИ ПРИСТУП ОБРАДИ ПЕСМЕ НАУЧИТЕ ПЈЕСАН МИОДРАГА ПАВЛОВИТА
}

АПСТРАКТ: У раду се с методичког аспекта разматрају могућности обраде песме Миодрага Павловића Научите пјесан у средњошколској настави. Циљ рада је осветљавање одговарајућих методичких поступака у вези с тумачењем лингвостилистичких особености. Анализом лингвостилистичких особености дошло се до закључка да је песма структурирана на принципима аналогије и контраста и на формалном и на идејном плану. По фреквенцији се издвајају две групе лексема: оне које негативну конотацију задобијају у контексту и глаголи у односу парцијалне синонимије, обједињени архисемом 'производити глас'. Архаизам пјесан представља стилску доминанту и својим широким упућивачким значењем реферише на реч/говор као творевину људског духа.

Кључне речи: Научите пјесан, Миодраг Павловић, лингвостилистичке особености, принципи аналогије и контраста, стилски маркирана лексика, глаголски синоними, реч/говор.

\section{LINGUISTIC STYLISTIC APPROACH IN THE INTERPRETATION OF THE POEM NAUČITE PJESAN WRITTEN BY MIODRAG PAVLOVIĆ}

ABSTRACT: This paper considers possible interpretations of the poem Naucite pjesan written by Miodrag Pavlović regarding the methodical aspect in the secondary school curricula. The aim of this paper is to highlight the corresponding methodical procedures with regard to the interpretation of the linguistic stylistic particularities. The analysis of the linguistic stylistic characteristics brings about the conclusion that the poem is structured on the principles of analogy and contrast including the formal and conceptual plan. When frequency is concerned two groups of lexemes can be distinguished: those that have a negative connotation in the context and verbs in correlation with partial synonymy, united by the arch-semantic structure to produce a voice. The archaism pjesan represents a stylistic dominant and its broad meaning refers to the word/speech as a creation of human spirit.

Key words: Naučite pjesan, Miodrag Pavlović, linguistic stylistic peculiarities, principles of analogy and contrast, stylistically marked words, verb synonyms, word/speech. 


\section{1. УВОД}

Циљеви рада тичу се анализе лингвостилистичких особености песме Миодрага Павловића Научите пјесан, „смисаоног гесла целокупне његове поезије” (Поповић 2010: 257), која се изучава у четвртом разреду средње школе, у оквиру наставне теме Смисао и задаци проучавања књижевности. Сматрамо да лингвостилистички приступ књижевном тексту може допринети дубљој и свеобухватнијој методичкој интерпретацији и олакшаној рецепцији, уз уважавање естетских и сазнајних задатака. Притом, овакво се поступање показује нарочито оправданим у четвртом разреду средње школе, кад се очекује систематизовање градива из језика и књижевности, изучавано у претходним разредима, стога оно погодује функционалном прожимању ових двеју области.

Језик поезије Миодрага Павловића био је предмет истраживача, али, колико нам је познато, не и језичке особености ове песме (сем узгред и у фрагментима, сагледане кроз призму његове целокупне поезије). Уз то, своја гледишта о језику сам Миодраг Павловић изложио је у својим аутопоетичким есејима. $^{1}$

Посматраћемо структурне одлике песме, дистрибуцију, семантику ${ }^{2}$ и стилску вредност употребљене лексике. Осврнућемо се и на уочене графостилистичке поступке.

\section{2. ПРИНЦИПИ АНАЛОГИЈЕ И КОНТРАСТА ${ }^{3}$}

На самом почетку ученици се могу упутити да обрате пажњу на језичку организацију текста, нарочито на следеће:

- распоред синтаксичких јединица;

- синтаксичко окружење, те спојивост лексема са другим лексемама;

1 Између осталог, о томе и о изучаваоцима који су се бавили језиком Миодрага Павловића исп. Милановић 2010 и тамо приложену литературу.

2 Све семантичке интерпретације лексема у овом раду изнећемо унеколико прилагођене према лексикографским дефиницијама из једнотомног Речника српскога језика (даље: РСЈ). Као контролним речником служићемо се Речником српскохрватског књижевног и народног језика (даље РСАНУ), што ћемо посебно истаћи. Нећемо наводити сва описана значења, већ само она која сматрамо релевантним за контекст у ком су лексеме употребљене.

${ }^{3}$ Послужили смо се терминологијом коришћеном у: Штасни 2012: 32-34. 
- композицију.

Сугерише им се да у вези с наведеним уоче сличности и разлике на формалном и идејном плану, односно где се и како остварују принципи аналогије и контраста.

Ученици треба да запазе да се принцип аналогије огледа у формалном паралелизму, те у симетрији синтаксичких јединица на синтаксичком и синтагматском плану, што ћемо илустровати табеларно.

\begin{tabular}{|c|c|c|}
\hline независна реченица + зависна & \multicolumn{2}{|c|}{ предлошко-падежна конструкција } \\
\hline $\begin{array}{c}\text { императив (/ императивна } \\
\text { конструкција) + временска } \\
\text { реченица }\end{array}$ & $\begin{array}{c}\text { кроз / уз + акузатив } \\
\text { (+ генитив })\end{array}$ & $\begin{array}{c}\text { c + инструментал + } \\
\text { инфинитив + } \\
\text { акузатив }\end{array}$ \\
\hline стојте мирно кад се зачује питање & Кроз каква друштва & $\begin{array}{c}\text { с напасником } \\
\text { облачити самуре }\end{array}$ \\
\hline $\begin{array}{c}\text { славословите док се храму не } \\
\text { пробије теме }\end{array}$ & $\begin{array}{c}\text { кроз какве људске } \\
\text { видике }\end{array}$ & $\begin{array}{c}\text { с цариником } \\
\text { завлачити руке }\end{array}$ \\
\hline $\begin{array}{c}\text { [стаклени прозор] нек се обрати } \\
\text { мору / } \\
\text { док не проклија сиње срце }\end{array}$ & $\begin{array}{c}\text { кроз злоходнике, } \\
\text { пауке-војнике }\end{array}$ & \\
\hline $\begin{array}{c}\text { ускликните, утројте, узхвалите / } \\
\text { док се и лобањи не отвори горњи } \\
\text { вид }\end{array}$ & $\begin{array}{c}\text { кроз шуме пошасника } \\
\text { кроз уши доушника } \\
\text { уз раме дволичника }\end{array}$ & \\
\hline
\end{tabular}

Табела 1. Симетрија синтаксичких јединица

Остварена симетрија може имати поетичких побуда, чије разматрање може одвести интерпретацију у жељеном смеру. Тако анафоричку редупликацију предлога кроз можемо тумачити у складу с идејним слојем који проналази упориште у митском мишљењу и фолклору, те с основном мишљу продирања, пробијања кроз непријатељско окружење, ${ }^{4}$ и то песмом, будући да „Одсуство гласа јесте хтонска карактеристика” (Раденковић 1996: $68)^{5}$

4 В. значења глагола проћи: б. продрети, пробити се, 9. фиг. снаћи се, издржати, прогурати.

5 О магијској функцији песме могу посведочити и латинске речи које означавају и певање и бајање: cantus (1. певање, глас, песма; 2. заклињање, бајање), carmen (1. 
Уз то, у бајању, сродном певању, улогу медијатора између човека и нечисте силе често има камен ${ }^{6}$ (Раденковић 1996: 42). Стога, кад је истеривање нечисте силе представљено као утеривање у одређени простор, оно се језички исказује предлогом у (Раденковић 1996: 49), као у стиху „Уちите кроз гусле у мраморно око”.

С друге стране, принцип контраста проткан је и кроз идејни слој песме, ${ }^{7}$ а уједно се огледа и у унутрашњој композицији, структурираној у две целине. Прва садржи имплицитну друштвену критику, прекоревање због неделатног, трпељивог понашања у временима која се циклично понављају. У другој песничкој целини лирски субјекат предлаже могуће решење, исказано насловом.

\section{3. ЗАДАЦИ ЗА УЧЕНИКЕ}

У даљем току рада ученици се информишу да ће испитивати лексику и остварене стилске поступке. Ученици се деле у групе, задају им се захтеви и задаци, које ће радити уз наставникову помоћ, а потом ће презентовати добијене резултате. Истраживаће:

I група - фреквенцију, врсту речи, творбене одлике именских речи;

II група - семантику именских речи;

III група - функцију и дистрибуцију глаголских облика;

песма, 2. прорицање, заклињање), cantio (1. песма, 2. заклињање), incanto (1. певати, 2. изговорити заклињање), incantator (врач, чаробњак). Наиме, и бајалачко шапутање и певање превазилазе ,једнострану усмереност људског говора, као социјалног чина, проширујући могућност општења и са бићима ван људског света”, с тим да се бајање „,'спушта' испод говора (шапутање), а други 'диже' изнад њега (певање)”. Повезује их и посебно емотивно расположење (Раденковић 1996: 30).

${ }^{6}$ Могућа су и другачија тумачења, те „мраморно око” може метонимијски означавати споменик као симбол непролазне славе, победе која ће се извојевати гуслама, односно песмом, али и надгробни споменик, чиме се наставна интерпретација може додатно проблематизовати.

7 Уп. нпр. опозицију стихова - „Кроз каква друштва треба још проћи, / кроз какве људске видике” : „ускликните, утројте, узхвалите, / док се и лобањи не отвори горњи вид" [истицање Т. И.], чиме се спочитава да се спас не може наћи у ономе што је доступно човековим чулима, те у ограничености материјалним добрима, већ у устремљености ка духовним висинама. 
IV група - примарна и секундарна значења глагола који кореспондирају са конструкцијом у наслову, те њихов значењски однос;

V група - особености интерпункције.

\section{4. ЛЕКСИКА}

Очекује се да ученици уоче врсте речи које доминирају у композиционим целинама и дођу до закључка да је оделитост композиционих целина уочљива и на лексичком плану. Наиме, у првој доминирају именске речи, у другој се по фреквенцији издвајају глаголи.

\section{1. Именске речи}

У прву композициону целину убрајају се облици: ${ }^{8}$ злоходник, пауквојник, пошасник, доуиник, дволичник, напасник, цариник, ${ }^{9}$ пандур, борац против откровењ . $^{10}$ Приметно је да се и овде принцип аналогије остварује на формалном плану у вези с употребом суфикса -ик (видик, злоходник, пауквојник, пошасник, доушник, дволичник, напасник, цзариник, праведник), чиме се остварује и додатни еуфонијски ефекат, те звуковни паралелизам. Да није реч о случајној правилности, већ о циљаном поступању, можда може посведочити избор лексеме дволичник уместо обичније дволичњак, која је у значењу дволичан човек, лицемер забележена и у РСЈ. Лексема дволичник забележена је у РСАНУ, али својом лексикографском дефиницијом упућује на лексему дволичњак, што потврђује да је она обичнија.

Употребљене лексеме се не подударају само на формалном, већ и на семантичком плану, будући да већином означавају непријатељско, претеће окружење, свет који напада и угрожава, те у контексту задобијају експресивну стилску вредност. У интерпретацији се притом треба задржати на тумачењу лексике која не припада ученичком активном лексичком фонду. Таква је лексема злоходник коју РСЈ не бележи, али су у РСАНУ посведочени облици злохотник, у значењу 'онај који некоме жели зло, злонамерник, непријатељ' и злоход која означава 'полажење, посету која слути на зло,

\footnotetext{
8 Лексеме наводимо у основном облику номинатива једнине мушког рода.

9 Лексема изариник је употребљена у свом секундарном значењу: 2. ист. онај који је скупљао римски порез у Јудеји (омражен као издајник и крвопија).

10 Перифразом боричи против откровења алудира се на библијска четири јахача Апокалипсе.
} 
несрећан пут', и уз коју су употребљени квалификатори песн. и нерасn. Негативну семантику носи и скована полусложеница паук-војник, и то захваљујући првом саставном делу, за шта потврду пружа РСАНУ - паук: 2. онај који друге увлачи у своје послове; особа која друге искоришћава, пљачка и сл.

Негативно конотиран ${ }^{11}$ је и придев сињи („сиње срце”), који се везује за појмове и појаве с извесном мистичном злокобношћу, као у примерима сиње море, сиња магла и сиња кукавица, где се он колористички приближава црној боји, те значењу 'кобан, несрећан', и 'далек, непознат' (Станић 2015: 87-88). ${ }^{12}$ Исти је случај и са избором придева мраморни (,мраморно око”) у односу на неутрални облик мермерни. Уп. значења која доносимо према РСАНУ - мраморан: 2.б. хладан, студен као мрамор, неосетљив, безосећајан; в. непомичан, укочен; ојађен, утучен; г. безгласан, нем, гробни; мрамор: 2. а. камен на месту нечије погибије; уопште место нечије погибије; б. камени споменик на нечијем гробу; мермеран: који је од мермера, који се односи на мермер.

Значајно је да ученици сагледају употребну вредност стилски маркиране лексике у односу на неутралне јединице, која се огледа у онеобичавању израза, исказивању емоционално обојеног тона и у складу је с општом тематиком и атмосфером песме - апокалипитичном визијом света који све људско угрожава.

\section{2. Глаголи}

\subsection{1. Функција и дистрибуцฺија глаголских облика}

У песми најфреквентнији (19), ${ }^{13}$ императив користи се за заповедно усмеравање, молбу, савет, упутство итд. (в. Пипер / Клајн 2013: 404-405). Притом, облик 2. л. множине ${ }^{14}$ употребљава се за упућивање на групу лица

\footnotetext{
11 Конотацију разликујемо од афективности. Посматрамо је као део лексичког значења, својство експресивности, које се сагледава у односу према неутралним јединицама (Драгићевић 2010: 56-58).

12 Уп. и значења придева сињи: 1. а. сив, сивкаст, пепељаст, просед, б. модар, плавкаст, љубичаст, 2. црн, таман, 3. фиг. а. јадан, кукаван, несрећан, жалостан, ојађен, б. тежак напоран (о терету).

${ }^{13}$ Овде убрајамо и императивну конструкцију за 3. л. нека + презент.

14 Уочљива је морфостилистичка употреба заменица. Њих нема у првом композиционом делу, што се поткрепљује употребом инфинитива као неличног
} 
(Пипер / Клајн 2013: 410), овде колектив, народ, ком дата упутства треба да помогну да се „клоне звери”. Уз то, асиндетски употребљеним облицима императива сугерише се динамичност, неумитност, неопходност обављања радње која треба да донесе спас, „избављење” без одлагања: „жаморите, жуборите, роморите, / [...] ускликните, утројте, узхвалите, / [...] попевајте, коледајте".

Како се не прецизира вршилац радње, ради уопштавања, те предочавања свевремености, у употреби је безлично требати уз инфинитив ${ }^{15}$ (в. Пипер / Клајн 2013: 165-166): ${ }^{16}$ „Кроз каква друштва треба још проћи”, „треба још ићи уз раме дволичника”) и рефлексивни пасив („кад се зачује питање”, „док се храму не пробије теме”, „док се лобањи не отвори горњи вид”.

С истим циљем придавања карактера универзалности, укидања временских граница, користи се и свевременски презент (Пипер / Клајн 2013: 390): „гледати пандуре како бију по кичми”, ,jaшy велике коње, вребају крв, / заседају праведнике и сваког ко се јави”, „као што мученичка крв нађе своје копље”, „усред овог рата који сећање брише”, „то је избављење”.

Презент у релативној употреби односи се на радњу која реферише на будућност: „док не проклија сиње срце”, „песма не покуљља на слеме”.

Кад се предвиђа радња у будућности, употребљава се и футур I: „Куда ће они који се клоне звери”, „ко ће међу вама да затвори врата”.

И при употреби крњег перфекта потврђују се његове особине експресивности и актуелности (Пипер / Клајн 2013: 393): „свуд се дигли борци против откровења”, чиме се имплицира да је зло присутно у садашњици.

Дакле, употреба глаголских облика мотивисана је њиховим значењима која су саображена контексту и идејном слоју.

глаголског облика. Тек на крају прве целине, у стиху „Куда ће они што се клоне звери?", употребљава се множинско они. Формом 3. л. множине личне заменице означава се удаљавање од говорног лица (лирског субјекта), да би у другој композиционој целини дистанца била укинута непосредним обраћањем у 2. лицу множине, кад лирски субјекат понуди конкретно решење.

15 Модални део предиката требати изостављен је у стиховима „с напасником облачити самуре, / с цариником завлачити руке у мошње, / гледати пандуре како бију по кичми".

16 Таква се конструкција именује изразом предикатски инфинитив (Пипер / Клајн 2013: 412-413). 
Сходно идеји 'проласка кроз' (непријатељско окружење) доминантан је глагол кретања $u \hbar u$ са својим префиксалима проћu, $y \hbar u$ : „Кроз каква друштва

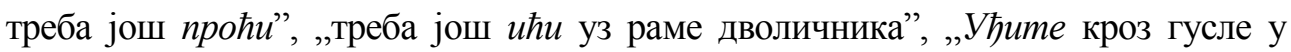
мраморно око".

Префикс $y$ - додат на глагол $u ћ u$ означава адлативно усмерено кретање, с обележјем интралокализованости, с обзиром на то да означава улазак у унутрашњост неког ограниченог, ограђеног, односно затвореног простора: ,yћu 'идући, крећући се, доспети у какав затворен, ограничен простор, у унутрашњост нечега"”.

Глаголи прећи и проћи имају пак значење перлативног усмереног кретања, „које се одвија у правцу прелажења неке путање: прећи 'идући преместити се или превести се преко чега, на другу страну', [...] проћи 'идући прећи преко каквог простора, отићи с једног места на друго, превалити какав пут”" (Вујовић 2012: 89).

\subsection{3. Глаголска синонимија}

У другој композиционој целини се по фреквенцији издвајају глаголи окупљени око глагола певати као прототипичног. Служећи се речницима при одређивању примарних и секундарних значења издвојених глагола, ученици треба да запазе на шта они реферишу, какав је њихов саоднос и, најзад, каква је њихова веза са перифрастичном конструкцијом у наслову, чиме би лакше растумачили идејни слој песме. Значења глагола ${ }^{17}$ приказаћемо табеларно.

\footnotetext{
17 За облик славословити нисмо пронашли одговарајућу лексикографску потврду, те смо се ослонили на сопствено језичко осећање, водећи се творбеном анализом облика. Такође, нисмо је пронашли ни за префиксале утројити, узхвалити, већ за њихове мотивне глаголе.
} 


\begin{tabular}{|c|c|}
\hline певати & $\begin{array}{l}\text { 1. а. изводити, интерпретирати мелодију, музичке тонове гласом, } \\
\text { б. изводити угодне, милозвучне тонове (о птицама певачицама), } \\
\text { 2. а. писати стихове, песме (као песник), б. славити песмом, } \\
\text { опевати (некога, нешто), 3. ир. говорити, причати }\end{array}$ \\
\hline орити се & снажно се разлегати, одјекивати (о песми, гласу, звуку) \\
\hline nојати & $\begin{array}{l}\text { 1. гласом изводити црквене песме, 2. певати (о птицама), } \\
\text { 3. опевавати у стиховима }\end{array}$ \\
\hline славословити & говорити у нечију славу ${ }^{18}$ \\
\hline жаморити & а. жагорити, грајати \\
\hline жуборити & 2. фиг. а. роморити, жагорити (о људима) \\
\hline роморити & $\begin{array}{c}\text { производити ромор, звучати једнолично, монотоно, шумити, } \\
\text { жуборити }\end{array}$ \\
\hline ускликнути & огласити се ускликом, узвикнути \\
\hline утројити & тројити (се): тростручити (се) $)^{19}$ \\
\hline узхвалити & $\begin{array}{c}\text { хвалити: 1. (некога, нешто) истицати нечије врлине, вредности, } \\
\text { лепоту и сл., похвално, ласкаво говорити о некоме, нечему; } \\
\text { величати, уздизати }\end{array}$ \\
\hline попевати & мало запевати \\
\hline коледати & певати коледу ${ }^{20}$ \\
\hline
\end{tabular}

Табела 2. Значења глагола

Поређењем њихових значења примећује се да они нису истозначни, већ да се одређене лексичко-семантичке групе могу уже груписати. Рецимо роморити, жаморати, жуборити; орити се, ускликнути и утројити по интензитету контрастирају глаголу попевати; глагол певати семантички је близак глаголима коледати и појати, с којим дели диференцијалну сему

${ }^{18}$ Уп. славопојка: песма, чланак, говор и сл. којима се неко или нешто слави, хвали, уздиже. В. и слово: 2. арх. а. реч, б. говор.

${ }^{19}$ Префиксал утројити свршени је видски парњак мотивном глаголу тројити, са значењем утростручити, како је забележено у РСЈ. Ипак, специфичност глагола утројити тиче се употребе у предвидљивом колокацијском споју с лексемом песма, што, мишљења смо, у већој мери одговара контексту песме.

${ }^{20}$ У РСЈ и РСАНУ лексеми коледати приписано је значење учествовати у коледи. Нашу интерпретацију доносимо сходно контексту песме и секундарном значењу лексеме коледа у РСЈ: б. песма која се том приликом пева [приликом коледе - коледа: етн. а. народни обичај у коме млади уочи Божића или Нове године иду од куће до куће, играју и певају народне песме са рефреном „коледо” изражавајући добре жеље - прим. Т. И.]. 
'интерпретирати песму', док се у свом секундарном значењу он приближава глаголу славословити (певати: б. славити песмом) и узхвалити; глаголима утројити и појати заједничка је везаност за религијску сферу. Такође, префиксалима попевати и узхвалити заједнички је неодређено-свршени видски лик, који се одликује типичним префиксима по- и за-, интензитетом и извесним временом вршења глаголске радње (Радић 2013: 58).

Сагледавањем односа примарних и секундарних значења можемо приметити да је синонимски низ устројен тако да се не односи искључиво на певање, песму, већ се његовим члановима реферише на жагор, усклик, хвалу, ритуал, итд., односно избором глагола побуђује се више асоцијација везаних за говор у најширем смислу, што кореспондира с избором лексеме пјесан. ${ }^{21}$ Перифразе уђите кроз гусле у мраморно око и научите пјесан јесу такође чланови синонимског низа глагола, обједињени архисемом 'производити глас/реч'. Отуда је могуће дубље заћи у семантику лексеме пјесан. Избављење које треба да донесе научена пјесан контрастира забораву које доноси рат (,усред овог рата који сећање брише, / научите пјесан, то је избављење”). Сећање се једино и може материјализовати путем речи, која ,је онтолошки знамен добра, посљедњи устук пред злом, и то она обредна, славословећа, с којом се једино може проћи кроз злоходнике и кроз шуме пошасника" (Поповић 2010: 257). Стога спас за којим се вапи у песми, одбрана од индивидуалног и колективног заборава, лежи у говору, у познавању речи, односно свега оног што се њоме чува, памти, акумулира, преноси - традиције, културног наслеђа, историјског памћења, итд.

\section{5. ГРАФОСТИЛИСТИКА}

Графостилистичке особености тичу се превасходно интерпункције. Упитник изостаје на крају дистиха, сачињеног од двеју довршених мисаоних целина: „Кроз каква друштва треба још проћи, / кроз какве људске видике, / кроз злоходнике, пауке-војнике, / кроз шуме пошасника, / кроз уши доушника, / треба још ићи уз раме дволичника, / с напасником облачити самуре, / с цариником завлачити руке у мошње, / гледати пандуре како бију по кичми!”. Прва два стиха

21 Употребом стилски неутралног облика песма побудио би се знатно мањи број асоцијација, и то искључиво везаних за певање. Тиме се само потврђује „да су архаизми оплемењени бројним конотацијама које савремени неутрални синоними немају, што је један од круцијалних узрока њиховог активирања у Павловићевој поезији” (Милановић 2010: 517-518). 
упитно су интонирана да би се у наредним тон променио, чиме се предочава познатост одговора на питање које се имплицира у дистиху. Одговор је лирском субјекту познат, сам га даје, сасвим свестан непријатељског окружења с којим се треба ухватити у коштац. Екскламацијом на самом крају се на тај начин и формално обележава градуирани емотивни набој.

Очигледно је и одсуство интерпунгирања при преношењу управног говора -,и стојте мирно кад се зачује питање / ко ће међу вама да затвори врата”. Изостанак интерпункције може бити ,[...] речит знак да аутору није стало до правилности [...]” (Кликовац 2019: 20), што верујемо да је у овом случају реч, те о намери да се дестабилизација на садржинском плану следи и на формалном.

Приметно је одсуство тачке у читавом другом композиционом делу. Будући да ,[...] потпуним или делимичним одсуством интерпункције пошиљалац имплицира да поруку треба читати 'у једном даху' [...]” (Кликовац 2019: 19), сугерише се стање душевне пренапрегнутости, страха од угрожавајуће опасности, због чега треба делати брзо, нагло, без премишљања.

Дакле, општи идејни слој подржан је и интерпункцијом.

\section{6. ЗАКЉУЧАК}

Анализа лингвостилистичких особености показала је да је песма структурирана на принципима аналогије и контраста и на формалном и на идејном плану.

Употребљена стилски маркирана лексика има експресивну стилску вредност и широка упућивачка значења, међу којима можемо издвојити архаизам пјесан као стилску доминанту. Поред лексике, стилску вредност има и интерпункција.

По фреквенцији се издвајају две групе лексема: именске речи које означавају непријатељско, претеће окружење и глаголи у односу парцијалне синонимије, обједињени архисемом 'производити глас/реч'.

Лингвостилистички приступ какав смо изложили, уз одређена прилагођавања, могуће је користити у наставној пракси, тим пре јер се чини погодним за утврђивање садржаја из морфологије, творбе речи, лексикологије и сродних дисциплина, те уједно за функционалну корелацију између језика и књижевности. Притом, он се не своди на пуко формално издвајање језичких одлика, већ се увиђањем и утврђивањем језичких особености унеколико олакшава рецепција дела, што је један од најважнијих методичких циљева и предуслов за остваривање свих методичких задатака. 


\section{ИЗВОР}

Бајић, Љ., Павловић, М., Мркаљ, 3. (2016). Читанка: српски језик и књижевност за четврти разред гимназија и средњих стручних школа. Београд: Klett [Bajić, Lj., Pavlović M., Mrkalj Z. (2016). Čitanka: srpski jezik $i$ književnost za četvrti razred gimnazija i srednjih stručnih škola. Beograd: Klett].

\section{ЛИТЕРАТУРА}

Вујовић, Д. (2012). Основна значења и префиксална деривација глагола $u \hbar и$ и ходати. Зборник Матице српске за филологију и лингвистику 55/2: 85-92 [Vujović, D. (2012). Osnovna značenja i prefiksalna derivacija glagola ići i hodati. Zbornik Matice srpske za filologiju i lingvistiku 55/2: 85-92].

Драгићевић, Р. (2010). Вербалне асоиијащије кроз српски језик и културу. Београд: Друштво за српски језик и књижевност Србије [Dragićević, R. (2010). Verbalne asocijacije kroz srpski jezik $i$ kulturu. Beograd: Društvo za srpski jezik i književnost Srbije].

Кликовац, Д. (2019). О стилским вредностима одсуства интерпункције. Къижевност и језик 66/1: 15-30 [Klikovac, D. (2019). O stilskim vrednostima odsustva interpunkcije. Književnost i jezik 66/1: 15-30].

Милановић, А. (2010). Језичка патина у поезији Миодрага Павловића. Песништво и књижевна мисао Миодрага Павловића. Београд: Институт за књижевност и уметност - Учитељски факултет: 507-526 [Milanović, A. (2010). Jezička patina u poeziji Miodraga Pavlovića. Pesništvo i književna misao Miodraga Pavlovića. Beograd: Institut za književnost i umetnost - Učiteljski fakultet: 507-526].

Пипер, П., Клајн, И. (2013). Нормативна граматика српског језика. Нови Сад: Матица српска [Piper, P., Klajn, I. (2013). Normativna gramatika srpskog jezika. Novi Sad: Matica srpska].

Поповић, Р. (2010). Обредни говор у поезији Миодрага Павловића. Песништво и књижевна мисао Миодрага Павловића. Београд: Институт за књижевност и уметност - Учитељски факултет: 245-259 [Popović, R. (2010). Obredni govor u poeziji Miodraga Pavlovića. Pesništvo i književna misao Miodraga Pavlovića. Beograd: Institut za književnost i umetnost - Učiteljski fakultet: 245-259]. 
Раденковић, Љ. (1996). Симболика света у народној магији Јужних Словена. Београд - Ниш: Балканолошки институт САНУ - Просвета [Radenković, Lj. (1996). Simbolika sveta u narodnoj magiji Južnih Slovena. Beograd - Niš: Balkanološki institut SANU - Prosveta].

Радић, С. (2013). О неодређено-свршеним глаголима у српском језику. Свет речи 35/36: 57-59 [Radić, S. (2013). O neodređeno-svršenim glagolima u srpskom jeziku. Svet reči 35/36: 57-59].

РСАНУ. Речник српскохрватског књижевног и народног језика, до 2020. изашло 20 томова. Београд: Српска академија наука и уметности, од 1959. године [RSANU. Rečnik srpskohrvatskog književnog $i$ narodnog jezika, do 2020. izašlo 20 tomova. Beograd: Srpska akademija nauka i umetnosti, od 1959. godine].

PCJ (2011). Речник српскога језика. Нови Сад: Матица српска [RSJ (2011). Rečnik srpskoga jezika. Novi Sad: Matica srpska].

Станић, Д. (2015). Систем назива за боје у лирској народној поезији (докторска дисертащија). Београд: Филолошки факултет [Stanić, D. (2015). Sistem naziva za boje u lirskoj narodnoj poeziji (doktorska disertacija). Beograd: Filološki fakultet].

Штасни, Г. (2012). Лингвостилистичка интерпретација лирске песме Грм. Методички видици 3: 29-46 [Štasni, G. (2012). Lingvostilistička interpretacija lirske pesme Grm. Metodički vidici 3: 29-46].

Tanja Ž. Ilić

University of Belgrade

Faculty of Philology

$\mathrm{PhD}$ program in Serbian language

\section{LINGUISTIC STYLISTIC APPROACH IN THE INTERPRETATION OF THE POEM NAUČITE PJESAN WRITTEN BY MIODRAG PAVLOVIĆ}

Summary

The paper reviews the possibilities of the interpretation of the poem Naucite pjesan written by Miodrag Pavlović in the secondary school curricula in order to highlight the corresponding methodical procedures regarding the interpretation of the linguistic stylistic particularities. The analysis includes external and internal compositions. When lexical composition are concerned, certain lexeme units were determined in correlation with 
the sphere of use. In the context of word classification verbs are distinguished so the paper also interprets the function, distribution and semantics of verb forms. The paper also reviews graphic stylistic procedures identified in the poem. The analysis of the linguistic stylistic characteristics brings about the conclusion that the poem was structured on the principles of analogy and contrast including the formal and conceptual plans. When frequency is concerned two groups of lexemes are distinguished: those that have a negative connotation in the context and verbs in correlation with partial synonymy, united by the arch-semantic structure to produce a voice/word. The archaism pjesan, given also in the title of the poem, represents a stylistic dominant and refers to both the word/speech as a creation of human spirit in its broad meaning and a defense against the individual and collective oblivion. The linguistic stylistic approach in the paper can be used with certain adjustments in the secondary school teaching practice preferably as a convenient mode for introducing morphology, word formation, lexicology, or similar disciplines, including a functional correlation between language and literature. Additionally, the analysis of the poem does not just formally single out language features, but also determines language particularities, expressive features and stylistic syntactic units complementing the places of vagueness. Such an approach facilitates to a certain extent the reception of the poem as one of the most important methodical aims and pre-conditions for the accomplishment of all methodical assignments.

Key words: Naučite pjesan, Miodrag Pavlović, linguistic stylistic peculiarities, principles of analogy and contrast, stylistically marked words, verb synonyms, word/speech. 


\section{Научите пјесан}

Кроз каква друштва треба још проћи, кроз какве људске видике, кроз злоходнике, пауке-војнике, кроз шуме пошасника, кроз уши доушника, треба још ићи уз раме дволичника, с напасником облачити самуре, с цариником завлачити руке у мошње, гледати пандуре како бију по кичми!

Свуда се дигли борци против откровења и јашу велике коње, вребају крв, заседају праведнике и сваког ко се јави између човека и бога, на брвну. Куда ће они што се клоне звери? Браните се! Научите песму! Уђите кроз гусле у мраморно око, певајте, орите се, појте и стојте мирно кад се зачује питање ко ће међу вама да затвори врата, славословите док се храму не пробије теме, стаклени прозор нек се обрати мору док не проклија сиње срце, жаморите, жуборите, роморите, нека вас нађе светло као срп своје снопље, као што мученичка крв нађе своје копље, ускликните, утројте, узхвалите, док се и лобањи не отвори горњи вид и песма не покуља на слеме, попевајте, коледајте, усред овог рата који сећање брише научите пјесан, то је избављење 